\title{
The Pollution of Ships' Ballast Water to the Marine Environment and Countermeasures
}

\author{
Yuan Jingguo \\ Foreign language department, Tianjin maritime collage Tianjin 300350 \\ yjg3024@126.com
}

Key words: ballast water; marine environment; ballast water exchange; heating-electrolysis

\begin{abstract}
: as the integration of the world economy, the amount of global trade has increased. 80\% of the trade commodities are transported by sea. A large number of ships whose ballast water cause great damage to the marine environment are sailing in the ocean every year. Ship's ballast water has become an important way for microorganisms transmitting all over the world. The pollution to the marine environment which is caused by ship's ballast water and the methods how to deal with ship' ballast water will be discussed in this paper.
\end{abstract}

\section{Introduction}

When the Ship navigates without any cargo, it is necessary for the ship to pump in some sea water to increase its stability so as to fight against the wind and the wave. When the ship arrives at the destination port, the sea water which has been pumped in at the other port will be discharged into the destination port, so the amount of seawater is called ballast water. Ship's ballast water plays an important role in adjusting the draft and trimming of the ship, reducing hull deformation, reducing hull resistance, lowering hull vibration, improving the seaworthiness of the ship and so on. If the ballast water contains harmful aquatic organisms or pathogens, and these ballast water is discharged into the waters of other ports, In this case, the marine ecological condition and local economy and human health will be affected. The damage to the marine environment which is caused by marine species in ship's ballast water has been recognized as one of the four major threats to the oceans by Global Environment Facility. Ship's ballast water pollution has been put a high premium by IMO(International Maritime Organization) and the governments of many countries, and they are studying how to deal with this issue of ballast water.

\section{The Marine Environment Pollution Caused by Ship's Ballast Water}

Ship's ballast water can be divided into two categories: one is the oil tank ballast water, and the other is the ballast from the ordinary holds of the ship. Some crude oil tankers don't have dedicated clean ballast tanks, so they use the oil tanks which have been carried out COW (crude oil washing) to carry ballast water, thus the oil residue which has been left in the oil tank will be discharged into the other port together with the ballast water when necessary. So this will cause oil pollution to the sea environment. The other category of ballast water pollution is the ordinary cargo holds are used as ballast tanks, in this case, there are noxious liquid substances, harmful substances and viruses, bacteria which are pumped in the port of infected areas and the like. As a preliminary appreciation, there is about 11 billion tons of ballast water transferring from one place to another globally every year. These ballast water are mainly from the ship's discharging port or some areas nearby. The ballast water will transfer about $3000 \sim 4000$ species of organisms every day globally, although Most aquatic organisms in ballast tanks can't tolerate the environment of no light, no oxygen, high iron concentration, and will die on the voyage, but few strong vitality of aquatic organisms are able to successfully reach the discharging port and can reproduce themselves in local waters. So they become invaders. Invasion of alien species can cause damage to the ecological balance of the waters of the port State, lead losses to the local economy. Ships carry ballast water full of pathogens may also have serious regional epidemic characteristics, leading to the spread of epidemics, which will cause threat of port State public health. In 2006,The State Environmental Protection Administration 
reported that: biological invasion which plays a major role caused direct economic losses to the country up to 57.4 billion RMB.

\section{The Methods of Dealing with Ship's Ballast Water}

In order to prevent the ship's ballast water causing pollution to the marine environment, there are many methods used to deal with ship's ballast water throughout the whole world at present. Mechanical method, physical method, and chemical method are used to deal with ballast water. More research has been done to chemical methods to deal with ballast water such as chlorination, electrolysis, strong ionization discharge treatment method. The following are some methods to deal with ship's ballast water:

Mechanical Method - deep Sea Ballast Water Exchange. Deep sea ballast water exchange is based on a theory that: freshwater, estuarine and coastal water organisms generally can't survive in the deep sea environment, on the other hand, the deep sea marine organisms can't survive in the coastal environment too, furthermore, deep-sea waters almost do no harm to human lives. To carry out this method, ships have to replace its ballast when she is sailing in deep sea whose depth is more than 200 meters and 200 nautical miles offshore. Ballast water exchange methods can be divided into emptying, overflowing and dilution method according to their different operation.

Emptying Method. The ship has to discharge all the ballast water which is pumped in at the coastal port, and clean the residue at the tank bilge, and then inject deep sea water into the ballast tank. Using this method the coastal ballast water can be $100 \%$ replaced by deep sea water, so it is recognized as the most effective and most practical method to prevent the spread of harmful aquatic organisms and pathogens. During the process of replacing the ballast water, the loading condition and stability of the ship will change significantly, so the ship officers must calculate the stability, trim, strength of the ship at each step of replacing process in advance so as to ensure the safe navigation. Emptying method is not suitable when the ship encounter bad weather, because it can't ensure the strength and stability of the ship.

Overflowing Method. This method is to pump the deep sea water into the full ballast tank from the tank bottom, so that the original coastal ballast water will overflow from the holes on top the deck. The ship has to pump in three times the amount of ballast water in order to replace $90 \%$ of the coastal ballast water. This method does not change the stability, strength and the trim of the ship, so it can be performed during adverse weather conditions. But the ballast water can't be replaced completely, the validity of this method is challenged. In addition, the ballast tanks will withstand overstress, sea water will form ice on deck in winter. These points will also make this method less safe, especially with respect to some old ships.

Dilution Method. This is a new method proposed by Brazil recently, which uses three times of deep sea water to replace the amount of the coastal ballast water from the top edge of the ballast tank, at the same time discharge the original ballast from the bottom of ballast tanks. Dilution method is safer than the overflowing method, but the effectiveness is not enough.

Physical Method. Heating Method. Focus on the study result so far, most organisms will be killed when they are put in the water whose temperature is between $38^{\circ} \mathrm{Cand} 50^{\circ} \mathrm{C}$ for $2 \sim 4 \mathrm{~h}$ duration. There are three kinds of ways to heat ballast water: press water vapor into the ballast water, heat the ballast water using the ship's main engine heat, or microwave method. Although this method is considered to be a potentially attractive approach, but it need a long processing time, high energy consumption, and also the safe navigation will be affected by the thermal stress at the same time.

Filtration. A certain size of organisms can be separated out from the ballast water by using onboard filtration system, which serve to prevent and reduce the harmful organisms from entering the ballast tank. Through this method, it is not necessary to exchange ballast water and some further operation steps. But in order to achieve more security filtering, some more detailed work has to be done. Because of the high flow speed and high flow during pumping in and pump out ballast water, it demands the filtration equipment has a good quality. And when biological and particle size 
becomes smaller, the complexity and cost of the filtration system will increase accordingly. The material filtered out from the ballast water can be stored on board and then receipted by shore facilities for further processing, it can't be discharged back to sea except the rules allow. Filtering system can choose the net filter or thick material filter.

Ultraviolet Irradiation. Studies have shown that if ultraviolet irradiation can kill the organisms is largely depending on the size and shape of the microorganism. When the wavelength is between $240 \sim 260 \mathrm{~nm}$, especially at $253.7 \mathrm{~nm}$, the organisms and pathogens in the ballast water will be easily killed. The main problem with this method is that there are large amounts of suspended material in the coastal water which will block ultraviolet radiate on biological pathogens. So combining ultraviolet irradiation method and filtration method will receive a better result. Furthermore, it will cost more when we use ultraviolet irradiation method to deal with ballast water.

Chemical Act method. Heating-electrolysis. To remove microorganism in the ballast water by using chlorination is feasible. But for different organisms, we have to use different chlorine to kill them. For details see table 3.1. Generally speaking, a small amount of chlorine can kill bacteria in ballast water; for plank tonic algae, because its tolerance to chlorine is strong, so it requires a higher chlorine content to kill plank tonic algae. When the seawater is heated to $38^{\circ} \mathrm{C} 45^{\circ} \mathrm{C}$, most algae and protozoa can't survive. We can produce chlorine using electrolysis of seawater. And the chlorine can kill all sea creatures and bacteria. Almost all bacteria in seawater will be killed when the concentration of chlorine reaches $20 \mathrm{mg} / \mathrm{L}$. There is an electrolysis system of seawater in the ballast water handling system which can produce chlorine to kill organisms in the ballast water. One way is to pump out some sea water from the main sea water pipe, and then send the sea water in to electrolysis apparatus to produce chlorine, and finally push the sea water full of chlorine in to the ballast tank. We have to control the concentration of chlorine less than $0.1 \mathrm{mg} / \mathrm{L}$ after all organisms has been killed. In this situation, it will do no harm to corrode the sea water pipes and will cause no secondary pollution. Another method is to install the electrical bait directly in the ballast handling system, all the sea water will pass through the electrolysis apparatus. It is difficult to control the concentration of chlorine and cause large power consumption. During the process of electrolyzing sea water and killing the organisms, a carcinogen chloroform (THM) will be produced. But the chloroform will decompose soon and almost cause no damage to the environment.

Table 1 Chlorine concentration needed to kill different organisms

\begin{tabular}{|c|c|c|c|c|}
\hline Organisms & Algae & Protozoon & Bacillus coli & All sea organisms \\
\hline $\begin{array}{c}\text { Chlorine concentration to } \\
\text { kill organisms }\end{array}$ & $5 \sim 10 \mathrm{mg} / \mathrm{L}$ & $5 \mathrm{mg} / \mathrm{L}$ & $5 \mathrm{mg} / \mathrm{L}$ & $20 \mathrm{mg} / \mathrm{L}$ \\
\hline
\end{tabular}

Strong Ionization Method. Institute of Environmental Engineering of Dalian Maritime University has developed a "strong ionization method to deal with ballast water so as to prevent invasion of harmful microorganisms" which can prevent the spread of harmful ballast water organisms effectively. This is a new method to deal with ship's ballast water. According to reports, the hydroxyl radical is a strong oxidant, it has the same oxidation reduction potential as fluorine, and it can easily kill microorganisms. Hydroxyl will cause the protein of invasive microorganisms to lose activity and died finally. In addition, the reaction between invasive microorganisms and hydroxyl is a free radical reaction whose reaction speed is very high. This reaction can kill the microorganisms during the process of pumping in the ballast water. But the technology is still in the laboratory stage, once recognized by IMO (International Maritime Organization),it will become an effective way to deal with ballast water pollution.

\section{Conclusion}

With the introduction of MARPOL (International Convention for the Prevention of Pollution from Ships) Convention, marine environmental protection has been focused by the international community. One of the important problems is how to prevent pollution caused by ships' ballast water. Dealing with ballast water is a complex issue demanding safety, reliability, effectiveness and economy. Exchange ballast water in deep sea during voyage is the most effective and practical 
method to deal with ship's ballast water so far. But there are security risks to the operation of the ship. Other methods described in this paper, although they are possible in theory, but there will be some shortcomings in the implementation process. Therefore, to develop more practical, more economical ballast water pollution prevention method is imperative. On the other hand, some vessels are equipped with ballast water system, but they do not use it because of the economy reason. Ballast water system is used only in the PSC inspection. In this case, it is important to establish supervising equipment for every ship in order to force them to use their ballast water system all the time.

\section{Reference}

[1] Bu Renxiang. Management of ship[M], Dalian. Dalian Maritime University press. 2012.8

[2] Chen Hong. Countermeasures to control ship' ballast water pollution [J] ENVIRONMENT AND SUSTAINABLE DEVELOPMENT. NO.6, 2007

[3]Ballast Water News, issue. April-Jun 2000. 1-8

[4]Oemeke. D. Treatment Of Ships? Ballast Water. Ecoprots Monograph Series.1999.18

[5]Zeng Xiaoyan. Practicability Study on dealing with ship' ballast water using electrolytic process [J] Navigation of china,2006, volume 67 (2), 83-85 